Available online on 15.03.2020 at http://jddtonline.info
Open Access to Pharmaceutical and Medical Research
unrestricted non-commercial use, provided the original work is properly cited

open $\odot$ Access

Research Article

\title{
Formulation development and in-vitro evaluation of Molsidomine matrix tablets for colon specific release
}

\author{
D. Hema Naga Durga*1, T. Lakshmi Sowjanya ${ }^{1}$, T. Pavani' ${ }^{1}$, and Lohithasu Duppala ${ }^{2}$ \\ ${ }^{1}$ AVANTHI Institute of Pharmaceutical Sciences, Cherukupally (V), Bhogapuram (M), Vizianagaram (D), A.P-531162 \\ 2 Division of Pharmaceutical Technology, A.U. College of Pharmaceutical Sciences, Andhra University, Visakhapatnam (D), A.P-530003
}

\begin{abstract}
Colon targeted tablets were prepared in two steps. Initially core tablets were prepared and then the tablets were coated by $\mathrm{u}$ sing different $\mathrm{pH}$ dependent polymers. Ethyl cellulose, Eudragit L100 and S100 were used as coating polymers. FT-IR studies were carried out to find out the possible interaction between the selected drugs and polymer. FT-IR studies revealed that there was no interaction between the selected drug and excipients. The pre-compression blend of all formulations was subjected to various flow property tests and all the formulations passed the tests. The tablets were coated by using polymers and the coated tablets were subjected to various evaluation techniques. The tablets passed all the tests. Among all the formulations F3 formulation was found to be optimized as it was retarded the drug release up to 12 hours and showed maximum of $97.57 \%$ drug release. It followed zero order kinetics mechanism. The ideal formulation was subjected to stability studies at $40^{\circ} \mathrm{C} / 75 \% \mathrm{RH}$. The stability studies indicated that the formulation was stable and retained its pharmaceutical properties at $40^{\circ} \mathrm{C} / 75 \% \mathrm{RH}$ over a period of 1 month.
\end{abstract}

Keywords: Colon target, Ethyl cellulose, Eudragit L100 and S100, pH dependent polymers.

Article Info: Received 13 Dec 2019; $\quad$ Review Completed 28 Jan 2020; $\quad$ Accepted 03 Feb 2020; Available online 15 March 2020

Cite this article as:

Naga Durga DH, Sowjanya TL, Pavani T, Duppala L, Formulation development and in-vitro evaluation of Molsidomine matrix tablets for colon specific release, Journal of Drug Delivery and Therapeutics. 2020; 10(2):59-68

http://dx.doi.org/10.22270/jddt.v10i2.3900

*Address for Correspondence:

Dr. D. Hema Naga Durga, Division of Pharmaceutics, AVANTHI Institute of Pharmaceutical Sciences, Cherukupally (V), Bhogapuram (M),

Vizianagaram (D), A.P-531162.

\section{INTRODUCTION}

The oral route is considered to be most convenient for administration of drugs to patients. Oral administration of conventional dosage forms normally dissolves in the stomach fluid or intestinal fluid and gets absorbed from these regions of the gastrointestinal tract (GIT) depending upon the physicochemical properties of the drug. Molsidomine is a nitrovasodilator that causes vasodilation (widening of blood vessels) by donation of nitric oxide (NO), and is mostly used for the treatment and prevention of angina pectoris. Oral absorption of Molsidomine is found to be $95.5 \% \pm 4.5$ and volume of distribution is found to be 98 litre ${ }^{1-5}$.

The aim of the present research work was to develop sustained release matrix formulation of Molsidomine targeted to colon by using various polymers and in-vitro drug release study. The objectives of the study were to prepare Molsidomine as a colon targeted tablet. Molsidomine matrix tablets containing several retarding agents separately were used in order to extend the release of drug over the desired period of time and also to evaluate these formulations by in-vitro methods and to select the best formulation among them. The formulations for physicochemical properties were evaluated and also interpret kinetic studies ${ }^{6-11}$.

\section{MATERIAL AND METHODS}

\section{Materials}

Molsidomine was gifted by M/s. Natco LABS, Ethyl Cellulose was purchased from M/s. Signet Chemical Corporation, Mumbai, India. Eudragit L-100, Eudragit S-100, Magnesium stearate, Micro crystalline cellulose, Talc were purchased from M/s. Merck Specialities Pvt Ltd, Mumbai, India.

\section{Methods}

\section{Analytical method development:}

\section{Determination of absorption maxima:}

A solution containing a concentration of $10 \mu \mathrm{g} / \mathrm{ml}$ was prepared in $0.1 \mathrm{~N} \mathrm{HCl}, 7.4 \mathrm{pH} \&$ phosphate buffer of $6.8 \mathrm{pH}$ 
respectively, UV spectrum was taken using Double beam UV/VIS spectrophotometer. The solution was scanned in the range of $200-400 \mathrm{~nm}$.

\section{Preparation of calibration curve:}

$10 \mathrm{mg}$ of drug was accurately weighed and dissolved in $10 \mathrm{ml}$ of $0.1 \mathrm{~N} \mathrm{HCl}, 7.4 \mathrm{pH}$, and $6.8 \mathrm{pH}$ in $10 \mathrm{ml}$ volumetric flask, to make $(1000 \mu \mathrm{g} / \mathrm{ml})$ standard stock solution (1). Then $1 \mathrm{ml}$ stock solution (1) was taken in another $10 \mathrm{ml}$ volumetric flask to make $(100 \mu \mathrm{g} / \mathrm{ml})$ standard stock solution (2), then again $1 \mathrm{ml}$ of stock solution (2) was taken in another $10 \mathrm{ml}$ volumetric flask and then final concentrations were prepared 2, 4, 6, 8, 10,12, 14, 16, 18, and $20 \mu \mathrm{g} / \mathrm{ml}$ with $0.1 \mathrm{~N}$ $\mathrm{HCl}, 7.4 \mathrm{pH}$, and $6.8 \mathrm{pH}$. The absorbance of standard solution was determined using UV/ VIS spectrophotometer at 273nm. Linearity of standard curve was assessed from the square of correlation coefficient $\left(\mathrm{r}^{2}\right)$ which determined by least-square linear regression analysis ${ }^{12,13}$.

\section{Drug-Excipient compatibility studies Fourier Transform Infrared (FTIR) spectroscopy:}

The physical properties of the physical mixture were compared with those of plain drug. Samples was mixed thoroughly with $100 \mathrm{mg}$ potassium bromide IR powder and compacted under vacuum at a pressure of about 12 psi for 3 minutes. The resultant disc was mounted in a suitable holder in Perkin Elmer IR spectrophotometer and the IR spectrum was recorded from $3500 \mathrm{~cm}$ to $500 \mathrm{~cm}$. The resultant spectrum was compared for any spectrum changes.

\section{Pre-formulation parameters}

The quality of tablet, once formulated by rule, is generally dictated by the quality of physicochemical properties of blends. There are many formulations and process variables involved in mixing and all these can affect the characteristics of blends produced. The various characteristics of blends tested as per Pharmacopoeia ${ }^{14,15}$.

\section{Angle of repose:}

The frictional force in a loose powder can be measured by the angle of repose. It is defined as, the maximum angle possible between the surface of the pile of the powder and the horizontal plane. If more powder is added to the pile, it slides down the sides of the pile until the mutual friction of the particles producing a surface angle, is in equilibrium with the gravitational force. The fixed funnel method was employed to measure the angle of repose. A funnel was secured with its tip at a given height (h), above a graph paper that is placed on a flat horizontal surface ${ }^{16,17}$. The blend was carefully pored through the funnel until the apex of the conical pile just touches the tip of the funnel. The radius (r) of the base of the conical pile was measured. The angle of repose was calculated using the following formula:

$\operatorname{Tan} \theta=\mathbf{h} / \mathbf{r}$

\section{Tan $\theta=$ Angle of repose}

$\mathrm{h}=$ Height of the cone, $\mathrm{r}=$ Radius of the cone base

Table 1: Angle of Repose values (as per USP)

\begin{tabular}{|c|c|}
\hline Angle of Repose & Nature of Flow \\
\hline$<25$ & Excellent \\
\hline $25-30$ & Good \\
\hline $30-40$ & Passable \\
\hline$>40$ & Very poor \\
\hline
\end{tabular}

\section{Bulk density:}

Density is defined as weight per unit volume. Bulk density, is defined as the mass of the powder divided by the bulk volume and is expressed as gm/ $\mathrm{cm}^{3}$. The bulk density of a powder primarily depends on particle size distribution, particle shape and the tendency of particles to adhere together. Bulk density is very important in the size of containers needed for handling, shipping, and storage of raw material and blend. It is also important in size blending equipment. $10 \mathrm{gm}$ powder blend was sieved and introduced into a dry $20 \mathrm{ml}$ cylinder, without compacting ${ }^{18,19}$. The powder was carefully leveled without compacting and the unsettled apparent volume, Vo, was read.

The bulk density was calculated using the formula: Bulk Density $=\mathrm{M} / \mathrm{V}_{\mathrm{O}}$

Where, $\mathrm{M}=$ weight of sample

$\mathrm{V}_{\mathrm{O}}=$ apparent volume of powder

\section{Tapped density:}

After carrying out the procedure as given in the measurement of bulk density the cylinder containing the sample was tapped using a suitable mechanical tapped density tester that provides 100 drops per minute and this was repeated until difference between succeeding measurement is less than $2 \%$ and then tapped volume, $\mathrm{V}$ measured, to the nearest graduated unit ${ }^{20,21}$. The tapped density was calculated, in gm per $\mathrm{L}$, using the formula:

$$
\text { Tap }=\text { M / V Where, Tap= Tapped Density }
$$

$\mathrm{M}=$ Weight of sample

$\mathrm{V}=$ Tapped volume of powder

\section{Measures of powder compressibility:}

The Compressibility Index (Carr's Index) is a measure of the propensity of a powder to be compressed. It is determined from the bulk and tapped densities. In theory, the less compressible a material the more flowable it is. As such, it is measures of the relative importance of interparticulate interactions. In a free- flowing powder, such interactions are generally less significant, and the bulk and tapped densities will be closer in value 22 .

For poorer flowing materials, there are frequently greater interparticle interactions, and a greater difference between the bulk and tapped densities will be observed. These differences are reflected in the Compressibility Index which is calculated using the following formulas:

Carr's Index $=[($ tap $-\mathrm{b}) /$ tap $] \times 100$

Where, $\mathrm{b}=$ Bulk Density Tap $=$ Tapped Density

Table 2: Carr's index value (as per USP)

\begin{tabular}{|c|c|}
\hline Carr's index & Properties \\
\hline $5-15$ & Excellent \\
\hline $12-16$ & Good \\
\hline $18-21$ & Fair to Passable \\
\hline $2-35$ & Very Poor \\
\hline $33-38$ & Very Very Poor \\
\hline
\end{tabular}




\section{Formulation development of Tablets:}

Molsidomine colon targeted tablets were prepared by using compression coating technology. Initially internal core tablet containing drug and super disintegrate was formulated. For the prepared core tablet compression coating is done by using various compositions of polymers. Ethyl cellulose, Polymethacrylate polymers such as Eudragit L100 and Eudragit S100 are used as polymers for compression coating.

Tablets are developed in two stages

1) Preparation of core tablet containing drug and super disintegrate.

2) Compression coating of prepared core tablets.

\section{Formulation of core tablet:}

The core tablets are formulated by using $250 \mathrm{mg}$ of drug molecule, sodium starch glycollate as super disintegrate, Micro crystalline cellulose as iluents, talc and magnesium stearate as Glidant and Lubricant respectively. The composition of core tablet was given in below table.
Table 3: Composition of core tablet

\begin{tabular}{|c|c|}
\hline Ingredient Name & Quantity (mg) \\
\hline Molsidomine & 8 \\
\hline Sodium starch glycollate & 30 \\
\hline Talc & 5 \\
\hline Magnesium stearate & 5 \\
\hline MCC pH102 & 52 \\
\hline Total weight & 100 \\
\hline
\end{tabular}

Total weight of core tablet was fixed as $100 \mathrm{mg}$. The tablets are prepared by using $6 \mathrm{~mm}$ flat punch. Then the prepared core tablets are subjected to compression coating by using various compositions of polymers.

\section{Formulation of compression coated tablets:}

The prepared core tablets were subjected to compression coating by using various compositions of polymers such as Ethyl cellulose, Eudragit L 100 and Eudragit S 100 as coating materials. The composition of coating layer is given in below table.

Table 4: Composition of coating layer

\begin{tabular}{|c|c|c|c|c|c|c|c|c|c|}
\hline Ingredient name & F1 & F2 & F3 & F4 & F5 & F6 & F7 & F8 & F9 \\
\hline Ethyl cellulose (mg) & 50 & 100 & - & - & - & - & 50 & - & 50 \\
\hline Eudragit S100 (mg) & - & - & 50 & 100 & - & - & 50 & 50 & - \\
\hline Eudragit L100 (mg) & - & - & - & - & 50 & 100 & - & 50 & 50 \\
\hline Magnesium stearate (mg) & 3 & 3 & 3 & 3 & 3 & 3 & 3 & 3 & 3 \\
\hline Talc (mg) & 3 & 3 & 3 & 3 & 3 & 3 & 3 & 3 & 3 \\
\hline MCC pH 102 (mg) & 144 & 94 & 144 & 94 & 144 & 94 & 94 & 94 & 94 \\
\hline Total weight & 200 & 200 & 200 & 200 & 200 & 200 & 200 & 200 & 200 \\
\hline
\end{tabular}

Compression coating layer was divided into two equal portions i.e., $50 \mathrm{mg}$ of each quantity .Half of the quantity of powder blend was placed in the die cavity, core tablet was placed exactly in the middle of die cavity and then remaining quantity of powder blend was placed over the core tablet so that the powder blend should cover all the sides and top side of core tablet uniformly. Then the tablets are compressed by using $9 \mathrm{~mm}$ flat surfaced punch using 8 station tablet punching machine with the hardness of $4-4.5 \mathrm{~kg} / \mathrm{cm}^{2}$.Then the prepared compression coted tablets are evaluated for various post compression parameters as per standard specifications.

Evaluation of post compression parameters for prepared Tablets

The designed formulation compression coated tablets were studied for their physicochemical properties like weight variation, hardness, thickness, friability and drug content.

\section{Weight variation test:}

To study the weight variation, twenty tablets were taken and their weight was determined individually and collectively on a digital weighing balance. The average weight of one tablet was determined from the collective weight. The weight variation test would be a satisfactory method of deter mining the drug content uniformity. Not more than two of the individual weights deviate from the average weight by more than the percentage shown in the following table and none deviate by more than twice the percentage. The mean and deviation were determined. The percent deviation was calculated using the following formula.

$\%$ Deviation $=$

(Individual weight-Average weight / Average weight) $\times 100$ 
Table 5: Pharmacopoeial specifications for tablet weight variation

\begin{tabular}{|c|c|c|}
\hline $\begin{array}{c}\text { Average weight of tablet } \\
\text { (mg) (I.P) }\end{array}$ & $\begin{array}{c}\text { Average weight of tablet } \\
\text { (mg) (U.S.P) }\end{array}$ & $\begin{array}{c}\text { Maximum percentage } \\
\text { difference allowed }\end{array}$ \\
\hline Less than 80 & Less than 130 & 10 \\
\hline $80-250$ & $130-324$ & 5.5 \\
\hline More than & More than 324 & 5 \\
\hline
\end{tabular}

\section{Hardness:}

Hardness of tablet is defined as the force applied across the diameter of the tablet in order to break the tablet. The resistance of the tablet to chipping, abrasion or breakage under condition of storage transformation and handling before usage depends on its hardness. For each formulation, the hardness of three tablets was determined using Monsanto hardness tester and the average is calculated and presented with deviation ${ }^{21,22}$.

\section{Thickness:}

Tablet thickness is an important characteristic in reproducing appearance. Tablet thickness is an important characteristic in reproducing appearance. Average thickness for core and coated tablets is calculated and presented with deviation.

\section{Friability:}

It is measured of mechanical strength of tablets. Roche friabilator was used to determine the friability by following procedure. Preweighed tablets were placed in the friabilator. The tablets were rotated at $25 \mathrm{rpm}$ for 4 minutes $(100$ rotations). At the end of test, the tablets were re weighed, loss in the weight of tablet is the measure of friability and is expressed in percentage as

$\%$ Friability $=[(\mathrm{W} 1-\mathrm{W} 2) / \mathrm{W}] \times 100$

Where, $\mathrm{W} 1=$ Initial weight of threetablets

W2 $=$ Weight of the three tablets after testing

\section{Determination of drug content:}

Both compression-coated tablets of were tested for their drug content. Ten tablets were finely powdered quantities of the powder equivalent to one tablet weight of Molsidomine were accurately weighed, transferred to a $100 \mathrm{ml}$ volumetric flask containing $50 \mathrm{ml}$ water and were allowed to stand to ensure complete solubility of the drug. The mixture was made up to volume with water. The solution was suitably diluted and the absorption was determined by UV -Visible spectrophotometer. The drug concentration was calculated from the calibrationcurve.

\section{In-vitro drug release studies}

\section{Drug release studies of Molsidomine core tablets:}

The core tablets containing $15 \mathrm{mg}$ of Molsidomine were tested in ( $\mathrm{pH}$ 6.8), for their dissolution rates. Dissolution studies were performed using USP paddle type sample of 5 $\mathrm{ml}$ was withdrawn and replaced with equal volume of fresh medium. The samples were analyzed spectrophotometrically at respective $270 \mathrm{~nm}$.

Drug release studies of Compression coated Molsidomine tablets:

The release of Molsidomine from coated tablets was carried

ISSN: 2250-1177 out using USP paddle-type dissolution apparatus at a rotation speed of $50 \mathrm{rpm}$, and a temperature of $37 \pm 0.5^{\circ} \mathrm{C}$. For tablets, simulation of gastrointestinal transit conditions was achieved by using different dissolution media. Thus, drug release studies were conducted in simulated gastric fluid (SGF, pH 1.2) for the first 2 hours as the average gastric emptying time is about 2 hours. Then, the dissolution medium was replaced with enzyme- free simulated intestinal fluid ( SIF, pH 7.4) and tested for drug release for 3 hours, as the average small intestinal transit time is about 3 hours, and finally enzyme- free simulated intestinal fluid ( $\mathrm{SIF}, \mathrm{pH} 6.8$ ) was used upto 12 hours to mimic colonic $\mathrm{pH}$ conditions.

Drug release was measured from compression coated Molsidomine tablets, added to $900 \mathrm{ml}$ of dissolution medium. $5 \mathrm{ml}$ of sample was withdrawn every time and replaced with fresh medium, samples withdrawn at various time intervals were analyzed spectrophotometrically at $275 \mathrm{~nm}$ and 270 $\mathrm{nm}$ respectively. All dissolution runs were performed for six batches. The results were given with deviation.

\section{Application of release rate kinetics to dissolution data:}

Various models were tested for explaining the kinetics of drug release. To analyze the mechanism of the drug release rate kinetics of the dosage form, the obtained data were fitted into zero-order, first order, Higuchi, and KorsmeyerPeppas release model.

\section{Zero order release rate kinetics:}

To study the zero-order release kinetics the release rate data are fitted to the

following equation.

$$
\mathrm{F}=\mathrm{K}_{0} \mathrm{t}
$$

Where, ' $F$ ' is the drug release at time ' $\mathrm{t}$ ', and ' $\mathrm{K}_{\mathrm{O}}$ ' is the zero order release rate constant. The plot of $\%$ drug release versus time is linear.

First order release rate kinetics: The release rate data are fitted to the following equation

$$
\log (100-F)=k t
$$

A plot of log cumulative percent of drug remaining to be released vs. time is plotted then it gives first order release.

Higuchi release model: To study the Higuchi release kinetics, the release rate data were fitted to the following equation.

$$
\mathrm{F}=\mathrm{kt} 1 / 2
$$

Where, ' $k$ ' is the Higuchi constant.

In higuchi model, a plot of $\%$ drug release versus square root of time is linear.

\section{Korsmeyer and Peppas release model:}

The mechanism of drug release was evaluated by plotting the 
log percentage of drug released versus log time according to Korsmeyer- Peppas equation. The exponent ' $n$ ' indicates the mechanism of drug release calculated through the slope of the straight Line.

$$
\mathrm{Mt} / \mathrm{M} \infty=\mathrm{Kt}^{\mathrm{n}}
$$

Where, $\mathrm{Mt} / \mathrm{M}_{\infty}$ is fraction of drug released at time ' $\mathrm{t}$ ', $\mathrm{k}$ represents a constant, and ' $\mathrm{n}$ ' is the diffusional exponent, which characterizes the type of release mechanism during the dissolution process. For non-Fickian release, the value of $\mathrm{n}$ falls between 0.5 and 1.0; while in case of Fickian diffusion, $\mathrm{n}=0.5$; for zero-order release (case I I transport), $\mathrm{n}=1$; and for supercase II transport, $\mathrm{n}>1$. In this model, a plot of $\log$ $(\mathrm{Mt} / \mathrm{M} \infty)$ versus log (time) is linear.

\section{Hixson-Crowell release model:}

$$
(100-Q t)^{1 / 3}=100^{1 / 3}-\text { KHC.t }
$$

Where, $\mathrm{k}$ is the Hixson-Crowell rate constant.

Hixson-Crowell model describes the release of drugs from an insoluble matrix through mainly erosion. (Where there is a change in surface area and diameter of particles or tablets).

\section{Stability Studies:}

Optimized formulation was subjected to stability studies for three months at $40^{\circ} \mathrm{C}$ with $75 \pm 5 \% \mathrm{RH}$ as per ICH guidelines. The tablets were analysed for Hardness, In- vitro disintegration time, drug content and cumulative \% drug released till a period of 3 months.

\section{RESULTS AND DISCUSSION}

The present study was aimed to develop compression coated Molsidomine formulations for colon targeting using ethyl cellulose and enteric coating polymers like Eudragit L 100 and Eudragit S 100. All the formulations were evaluated for physicochemical properties and in-vitro drug release studies.

\section{Analytical Method}

Graphs of Molsidomine was taken in Simulated Gastric fluid (pH 1.2) and Simulated Intestinal Fluid (pH 6.8 and 7.4)

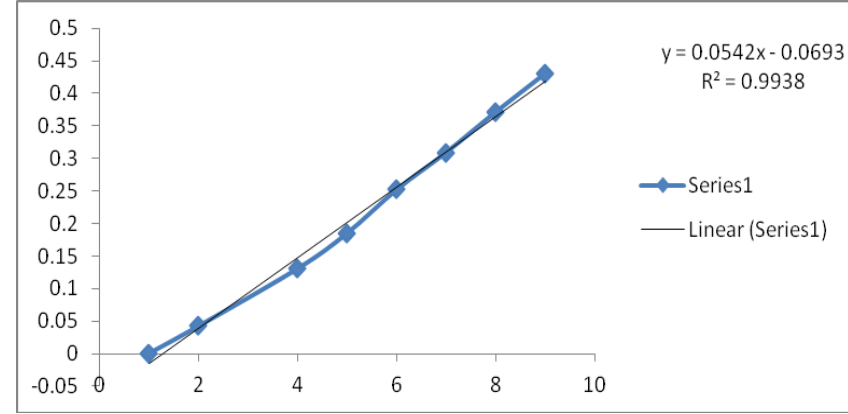

Fig 1: Standard graph of Molsidomine in $0.1 \mathrm{~N} \mathrm{HCl}$

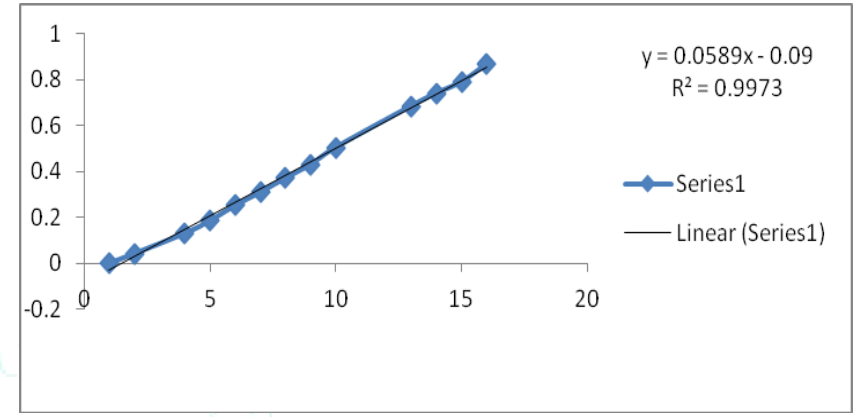

Fig 2: Standard graph of Molsidomine in $6.8 \mathrm{pH}$

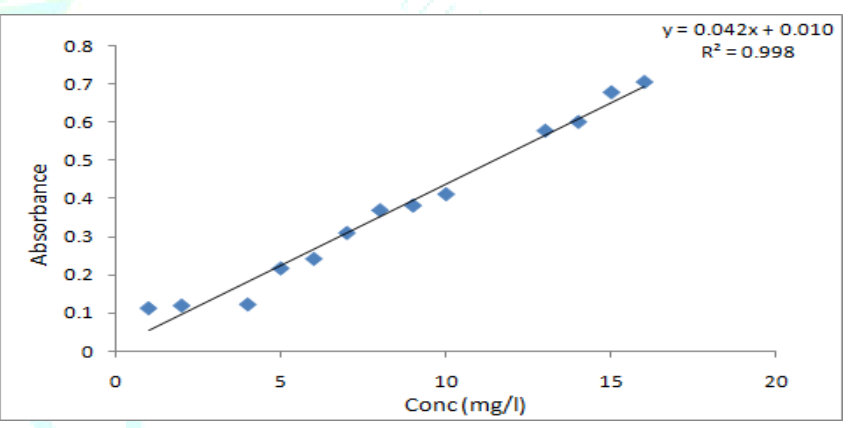

Fig 3: Standard graph of Molsidomine in $7.4 \mathrm{pH}$

\section{Drug and excipient compatibility studies:}

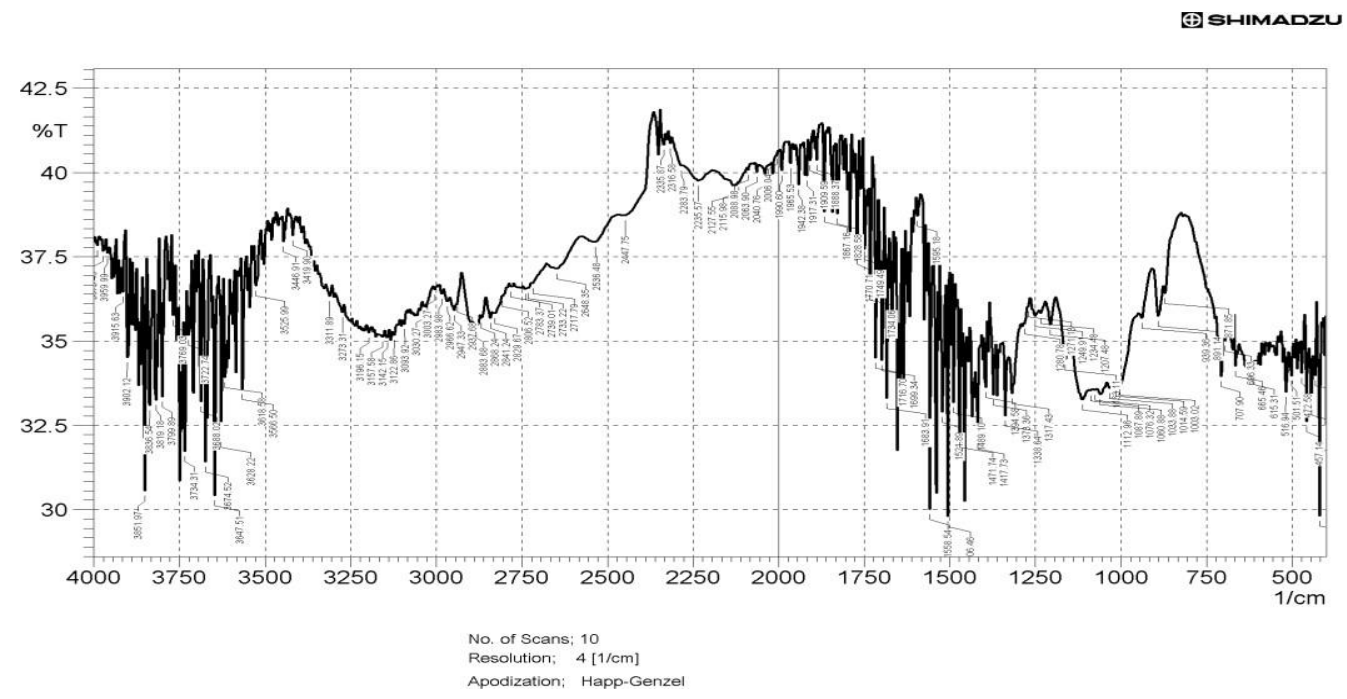

Fig 4: FT-IR spectrum of pure drug 


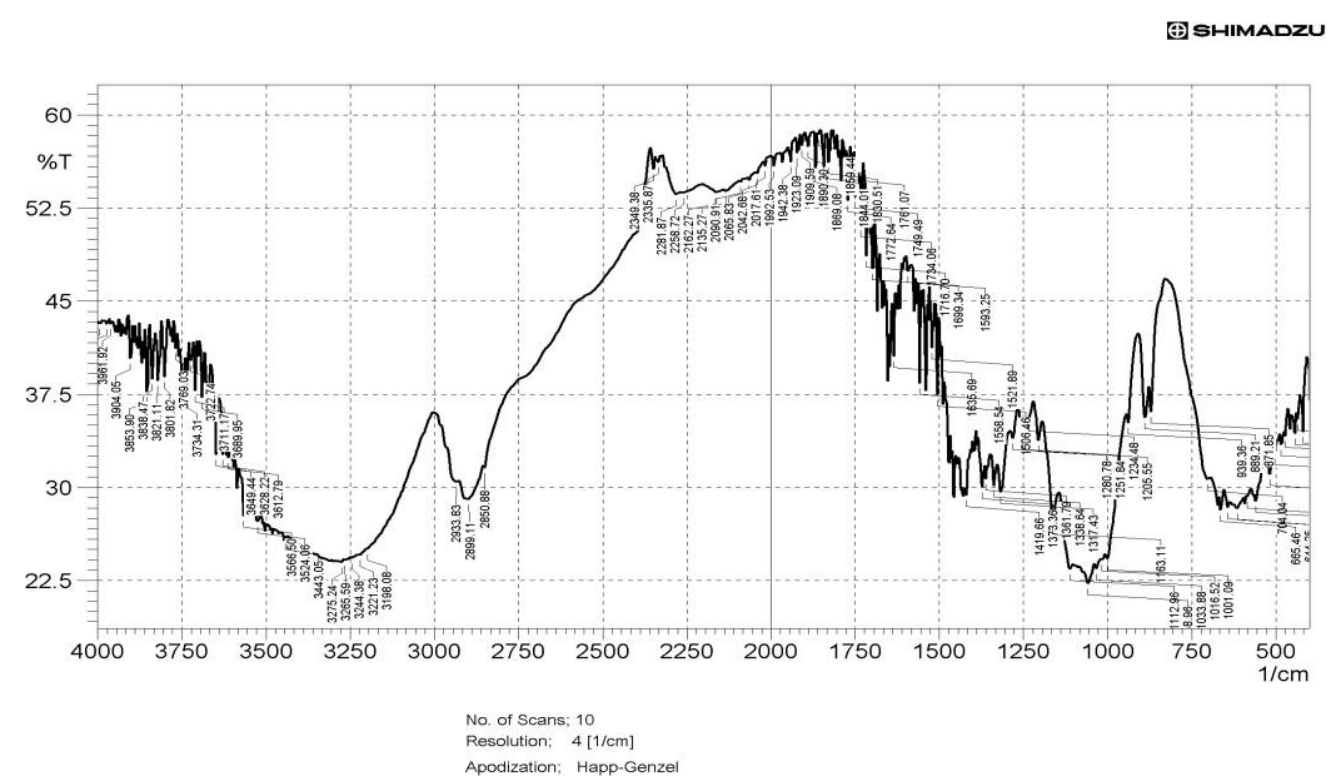

Fig 5: FT-IR spectrum of optimised formulation

Pre-formulation parameters

Table 6. Pre-formulation parameters of core material

\begin{tabular}{|c|c|c|c|c|c|}
\hline $\begin{array}{c}\text { Formulation } \\
\text { Code }\end{array}$ & Angle of Repose & $\begin{array}{c}\text { Bulk density } \\
\text { (gm/ml) }\end{array}$ & $\begin{array}{c}\text { Tapped density } \\
\text { (gm/ml) }\end{array}$ & $\begin{array}{c}\text { Carr's index } \\
\text { (\%) }\end{array}$ & Hausner's Ratio \\
\hline F1 & $36.01 \pm 0.11$ & $0.55 \pm 0.14$ & $0.645 \pm 0.24$ & $14.72 \pm 0.14$ & $0.85 \pm 0.19$ \\
\hline F2 & $34.8 \pm 0.18$ & $0.57 \pm 0.12$ & $0.66 \pm 0.22$ & $13.63 \pm 0.23$ & $0.86 \pm 0.24$ \\
\hline F3 & $32.74 \pm 0.17$ & $0.53 \pm 0.23$ & $0.606 \pm 0.27$ & $14.19 \pm 0.31$ & $0.858 \pm 0.17$ \\
\hline F4 & $35.33 \pm 0.22$ & $0.531 \pm 0.16$ & $0.613 \pm 0.29$ & $13.37 \pm 0.14$ & $0.866 \pm 0.26$ \\
\hline F5 & $36.24 \pm 0.13$ & $0.549 \pm 0.28$ & $0.641 \pm 0.18$ & $14.35 \pm 0.26$ & $0.856 \pm 0.31$ \\
\hline F6 & $36.12 \pm 0.24$ & $0.564 \pm 0.39$ & $0.666 \pm 0.19$ & $15.31 \pm 0.24$ & $0.846 \pm 0.24$ \\
\hline F7 & $37.08 \pm 0.6$ & $0.581 \pm 0.17$ & $0.671 \pm 0.12$ & $13.41 \pm 0.29$ & $0.865 \pm 0.29$ \\
\hline F8 & $35.12 \pm 0.15$ & $0.567 \pm 0.25$ & $0.654 \pm 0.13$ & $13.12 \pm 0.17$ & $0.845 \pm 0.11$ \\
\hline F9 & $35.45 \pm 0.25$ & $0.571 \pm 0.12$ & $0.689 \pm 0.15$ & $13.28 \pm 0.18$ & $0.855 \pm 0.18$ \\
\hline
\end{tabular}

Molsidomine blend was subjected to various pre-formulation parameters. The apparent bulk density and tapped bulk density values ranged from 0.52 to 0.581 and 0.606 to 0.671 respectively. According to tables, the results of angle of repose and compressibility index (\%) ranged from $32.74 \pm 0.12$ to $37.08 \pm 0.96$ and $13.37 \pm 0.38$ to $14.72 \pm 0.62$ respectively. The results of angle of repose $(<35)$ and compressibility index $(<23)$ indicates fair to passable flow properties of the powder mixture. These results show that the powder mixture has good flow properties. The formulation blend was directlycompressed to tablets and invitro drug release studies were performed.

\section{Quality Control Parameters for compression coated tablets:}

Tablet quality control tests such as weight variation, hardness, and friability, thickness, and drug release studies in different media were performed on the compression coated tablet. Total weight of tablet including core is $300 \mathrm{mg}$. 
Table 7. In-vitro quality control parameters for compression coated tablets $(n=3)$

\begin{tabular}{|c|c|c|c|c|c|}
\hline $\begin{array}{c}\text { Formulati on } \\
\text { codes }\end{array}$ & $\begin{array}{c}\text { Weight } \\
\text { variation (mg) }\end{array}$ & $\begin{array}{c}\text { Hardness } \\
\mathbf{( k g} / \mathbf{c m} \text { ) }\end{array}$ & $\begin{array}{c}\text { Friability (\% } \\
\text { loss) }\end{array}$ & $\begin{array}{c}\text { Thickness } \\
\text { (mm) }\end{array}$ & Drug content (\%) \\
\hline F1 & $312.5 \pm 0.24$ & $4.5 \pm 0.24$ & $0.52 \pm 0.14$ & $4.8 \pm 0.11$ & $99.76 \pm 0.19$ \\
\hline F2 & $305.4 \pm 0.11$ & $4.2 \pm 0.41$ & $0.54 \pm 0.24$ & $4.9 \pm 0.19$ & $99.45 \pm 0.24$ \\
\hline F3 & $298.6 \pm 0.18$ & $4.4 \pm 0.11$ & $0.51 \pm 0.32$ & $4.9 \pm 0.32$ & $99.34 \pm 0.18$ \\
\hline F4 & $310.6 \pm 0.21$ & $4.5 \pm 0.18$ & $0.55 \pm 0.19$ & $4.9 \pm 0.22$ & $99.87 \pm 0.36$ \\
\hline F5 & $309.4 \pm 0.32$ & $4.4 \pm 0.39$ & $0.56 \pm 0.29$ & $4.7 \pm 0.18$ & $99.14 \pm 0.17$ \\
\hline F6 & $310.7 \pm 0.17$ & $4.2 \pm 0.19$ & $0.45 \pm 0.11$ & $4.5 \pm 0.31$ & $98.56 \pm 0.29$ \\
\hline F7 & $302.3 \pm 0.41$ & $4.1 \pm 0.23$ & $0.51 \pm 0.27$ & $4.4 \pm 0.29$ & $98.42 \pm 0.15$ \\
\hline F8 & $301.2 \pm 0.38$ & $4.3 \pm 0.31$ & $0.49 \pm 0.18$ & $4.7 \pm 0.21$ & $99.65 \pm 0.41$ \\
\hline F9 & $298.3 \pm 0.31$ & $4.5 \pm 0.43$ & $0.55 \pm 0.19$ & $4.6 \pm 0.22$ & $99.12 \pm 0.11$ \\
\hline
\end{tabular}

All the parameters such as weight variation, friability, hardness, thickness and drug content were found to be within limits.

\section{In-Vitro Drug Release Studies}

The compression coated tablets containing 250mg of Molsidomine were tested in $6.8 \mathrm{pH}$ phosphate buffer solution for their dissolution rates. The release of Molsidomine from compression coated tablets was carried out using USP paddle-type dissolution apparatus at a rotation speed of $50 \mathrm{rpm}$, and a temperature of $37 \pm 0.5{ }^{\circ} \mathrm{C}$ For tablets, simulation of gastrointestinal transit conditions was achieved by using different dissolution media. Thus, drug release studies were conducted in simulated gastric fluid (SGF, pH 1.2) for the first 2 hours as the average gastric emptying time is about 2 hours. Then, the dissolution medium was replaced with enzyme- free simulated intestinal fluid ( SIF, pH 7.4) and tested for drug release for 3 hours, as the average small intestinal transit time is about 3 hours, and finally enzyme- free simulated intestinal fluid ( SIF, $\mathrm{pH} 6.8$ ) was used upto 12 hours to mimic colonic $\mathrm{pH}$ conditions.

Drug release was measured from compression coated Molsidomine tablets, added to $900 \mathrm{ml}$ of dissolution medium. $5 \mathrm{ml}$ of sample was withdrawn every time and replaced with fresh medium, samples withdrawn at various time intervals were analyzed spectrophoto metrically at $275 \mathrm{~nm}, 319$ and $320 \mathrm{~nm}$ respectively. All dissolution runs were performed for six batches.

Table 8: In-vitro drug release profile for coated formulations (F1-F9)

\begin{tabular}{|c|c|c|c|c|c|c|c|c|c|}
\hline $\begin{array}{c}\text { Time } \\
\text { (hrs) }\end{array}$ & F1 & F2 & F3 & F4 & F5 & F6 & F7 & F8 & F9 \\
\hline 1 & 5.42 & 0.26 & 0.34 & 2.39 & 1.11 & 1.44 & 8.06 & 2.65 & 1.32 \\
\hline 2 & 12.65 & 0.44 & 0.54 & 17.88 & 1.29 & 12.30 & 20.94 & 7.23 & 2.14 \\
\hline 3 & 23.56 & 4.65 & 1.26 & 30.45 & 11.71 & 24.44 & 30.26 & 18.19 & 2.90 \\
\hline 4 & 66.8 & 17.87 & 2.22 & 40.59 & 30.22 & 36.61 & 45.44 & 30.27 & 8.11 \\
\hline 5 & 86.9 & 29.18 & 3.05 & 55.01 & 40.18 & 47.30 & 63.86 & 42.06 & 17.72 \\
\hline 6 & 98.35 & 35.45 & 18.41 & 73.85 & 54.53 & 55.68 & 72.93 & 51.40 & 30.40 \\
\hline 7 & 99.76 & 61.04 & 30.05 & 91.92 & 63.88 & 67.53 & 90.23 & 69.13 & 51.64 \\
\hline 8 & -- & 74.24 & 48.69 & 96.11 & 80.53 & 78.72 & 97.32 & 78.45 & 61.59 \\
\hline 9 & -- & 88.13 & 55.38 & -- & 95.06 & 83.34 & -- & 85.67 & 74.97 \\
\hline 10 & -- & 96.39 & 72.34 & -- & 95.18 & 90.67 & -- & 98.45 & 84.18 \\
\hline 11 & -- & -- & 87.56 & -- & -- & 98.12 & -- & 98.12 & 91.87 \\
\hline 12 & -- & -- & 97.57 & -- & -- & -- & -- & -- & 95.45 \\
\hline
\end{tabular}


From the dissolution values it was evident that the formulations F3 \& F9 were retarded the drug release up to 12 hours, they shown drug release of 97.57 and $95.45 \%$ respectively. Formulations F1-F3 contains ethyl cellulose alone. As the concentration of ethyl cellulose increases retardation nature was increased. F3 formulation containing $150 \mathrm{mg}$ of ethyl cellulose was show almost negligible amount of drug release in first 3 hours from the 5 th hour onwards it shown drug release as the time proceeds slowly the polymer was undergone erosion and allowed the drug to come out from the dosage form. The formulation was retarded drug release up to 12 hours and it showed maximum drug release in 12 hours i,e., in colon region. Similarly the formulation F9 containing Eudragit L 100 in the concentration of $100 \mathrm{mg}$ also showed similar drug release pattern.

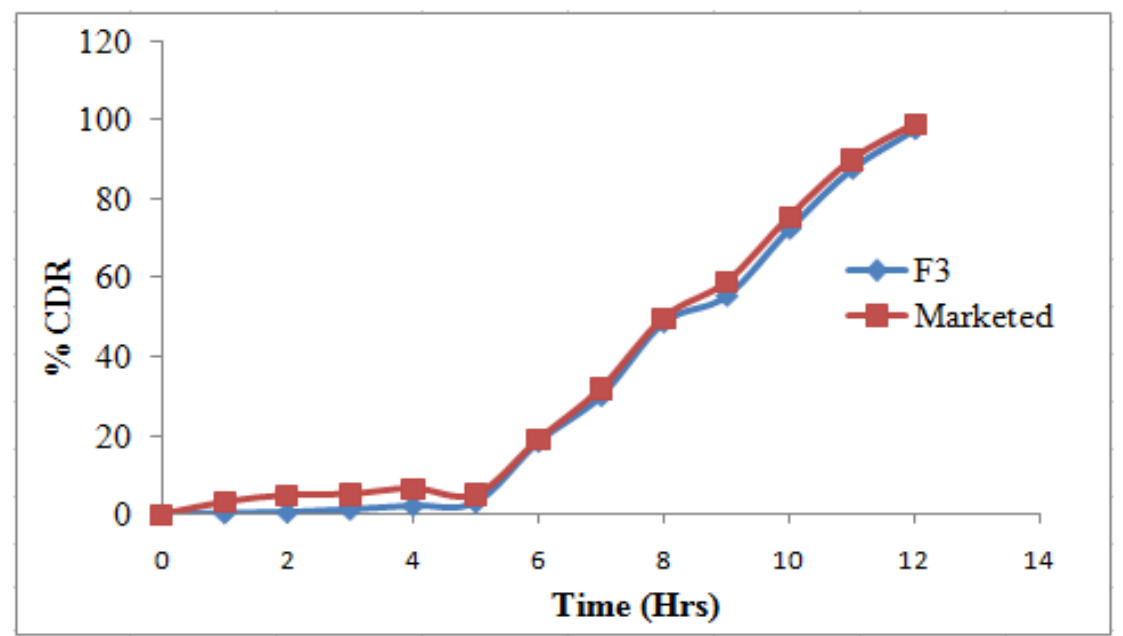

Fig 6: Comparison of In-vitro dissolution profile of CORVATON (Marketed product) with Optimized formulation (F3)

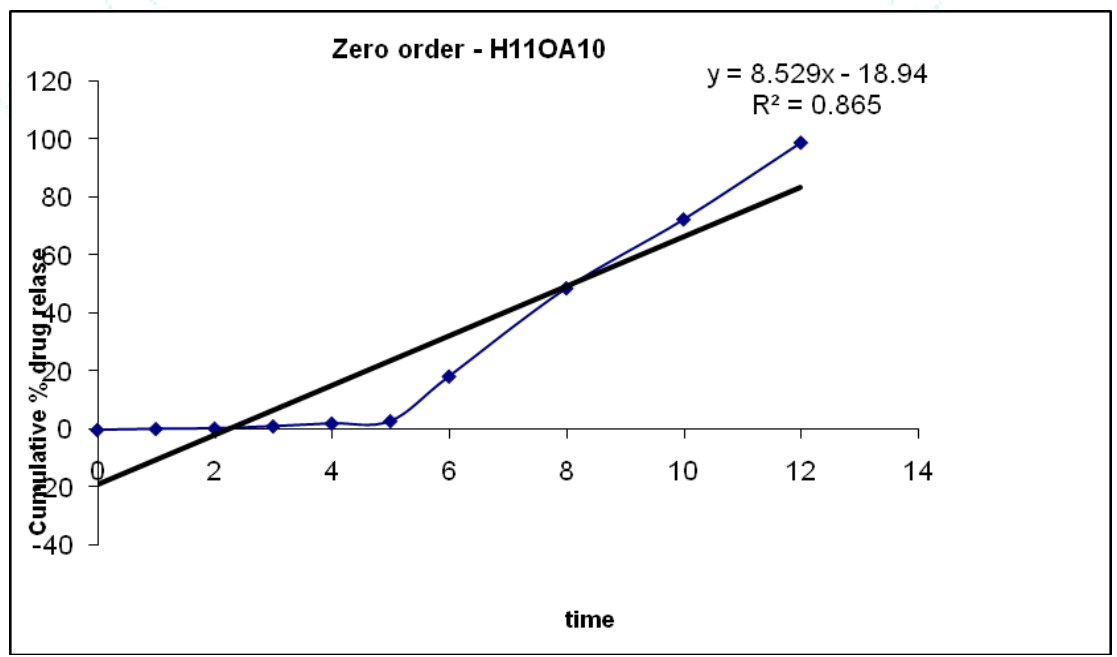

Fig 7: Zero order release kinetics graph

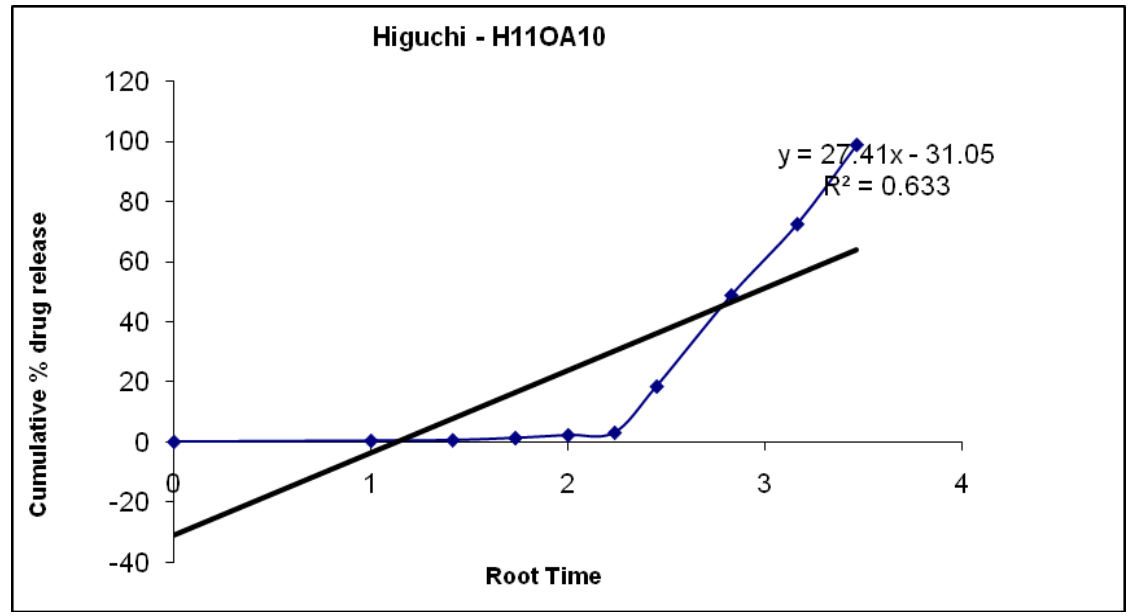

Fig 8: Higuchi release kinetics graph 


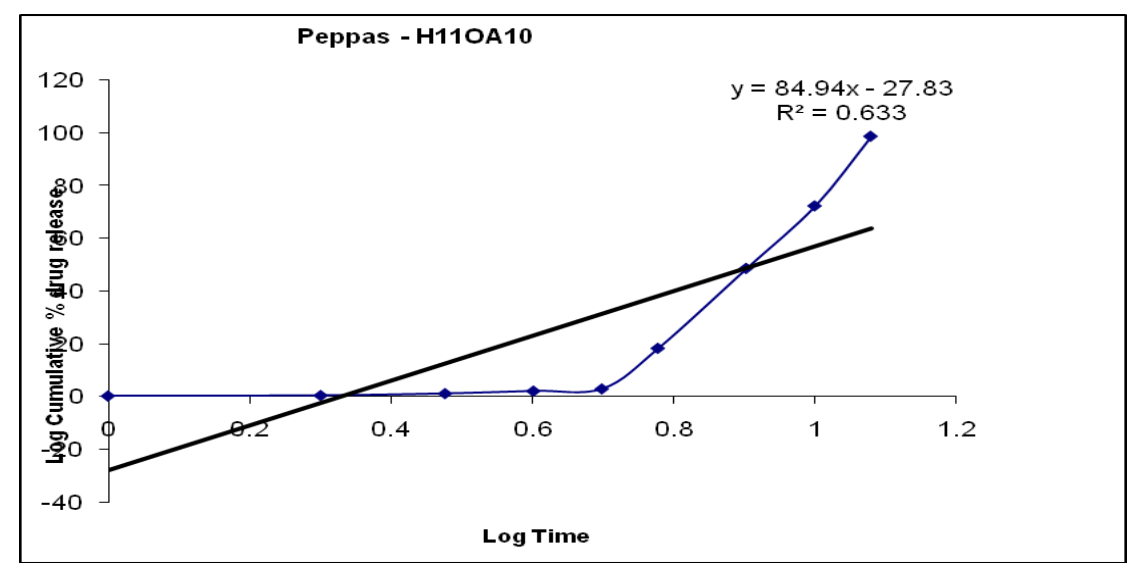

Fig 9: Korsmeyer peppas graph

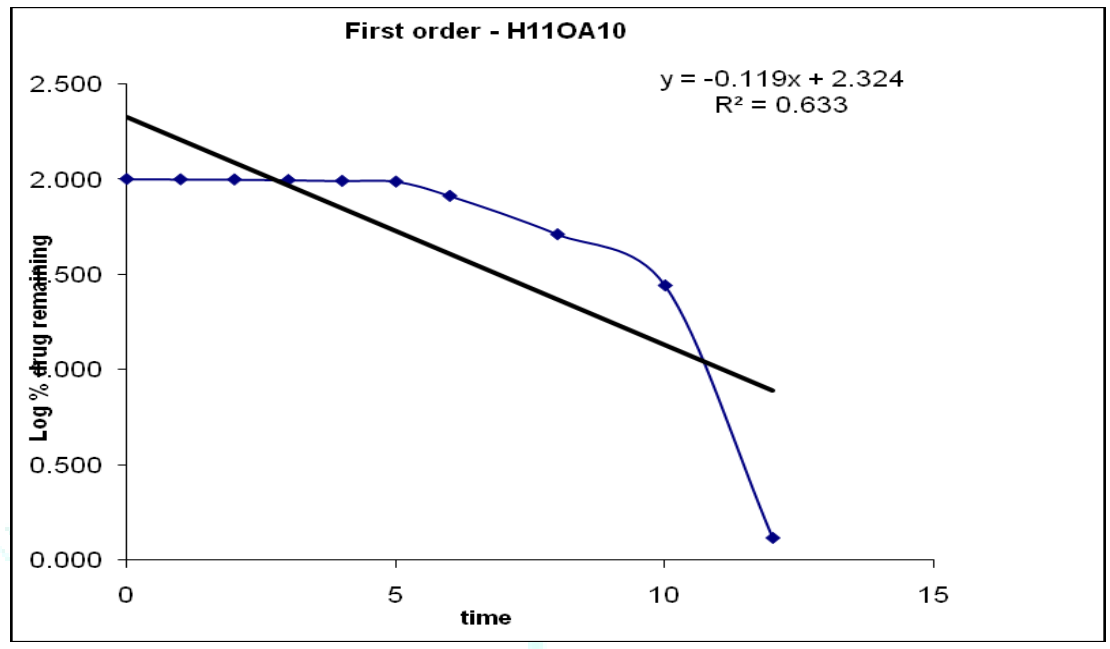

Fig 10: First order release kinetics graph

From the above graphs it was evident that the formulation F3 followed zero order kinetics.

\section{Stability Studies:}

Optimized formulation was subjected to stability studies for three months at $40^{\circ} \mathrm{C}$ with $75 \pm 5 \% \mathrm{RH}$ as per ICH guidelines. The tablets were analysed for hardness, in-vitro disintegration time, drug content and cumulative \% drug released till a period of 3 months.

Table 9: Stability studies of optimized formulation F3 (Three months at $40^{\circ} \mathrm{C}$ with $75 \pm 5 \% \mathrm{RH}$ )

\begin{tabular}{|c|c|c|c|c|}
\hline Parameters & Initial & $\begin{array}{c}\text { At the end of 1 } \\
\text { month }\end{array}$ & $\begin{array}{c}\text { At the end of 2 } \\
\text { month }\end{array}$ & $\begin{array}{c}\text { At the end of 3 } \\
\text { month }\end{array}$ \\
\hline Hardness $\mathbf{( K g / \mathbf { c m } ^ { \mathbf { 2 } } )}$ & $4.51 \pm 0.19$ & $4.49 \pm 0.10$ & $4.53 \pm 0.17$ & $4.47 \pm 0.11$ \\
\hline Wetting time (sec) & $32.63 \pm 0.26$ & $32.55 \pm 0.23$ & $32.45 \pm 0.25$ & $32.42 \pm 0.21$ \\
\hline Drug content (\%) & $99.31 \pm 0.24$ & $99.25 \pm 0.21$ & $99.29 \pm 0.29$ & $99.21 \pm 0.24$ \\
\hline $\begin{array}{c}\text { Cumulative percent } \\
\text { drug release }\end{array}$ & $97.57 \pm 0.18$ & $97.65 \pm 0.15$ & $97.51 \pm 0.12$ & $97.45 \pm 0.20$ \\
\hline
\end{tabular}

\section{CONCLUSION}

In the present research work sustained release matrix formulation of Molsidomine targeted to colon by using various polymers was developed. FT-IR studies revealed that there was no interaction between the selected drug and excipients. The pre-compression blend of all formulations was subjected to various flow property tests and all the formulations passed the tests. The tablets were coated by using polymers and the coated tablets were subjected to ISSN: 2250-1177 various evaluation techniques. The tablets passed all the tests. Among all the formulations F3 formulation was found to be optimized as it was retarded the drug release up to 12 hours and showed maximum of $97.57 \%$ drug release. It followed zero order kinetics mechanism. The ideal formulation was subjected to stability studies at $40^{\circ} \mathrm{C} / 75 \% \mathrm{RH}$. The stability studies indicated that the formulation was stable and retained its pharmaceutical properties at $40^{\circ} \mathrm{C} / 75 \% \mathrm{RH}$ over a period of 1 month. 
CONFLICT OF INTEREST: Authors have no conflict of interest to report.

\section{REFERENCES:}

1. Srinivas L, Lohithasu D, Madhupriya D, Siddhartha N, Tejaswi $\mathrm{N}$. Formulation and evaluation of ibuprofen pulsin cap technique for controlled release, Der Pharmacia Lettre, , 2013; 5 (1):60-68.

2. Hazee Peera N, Lohithasu D, Sahoo SK, Santhosh Naidu M, Mani Kumar K, Anil Kumar V. Formulation development and evaluation of oral disintegrating tablets of Zolmitriptan, Der Pharmacia Lettre, 2013; 5 (2):324-332.

3. Lohithasu D, Harsha INS, Krishna Swaroop K, Madhu G, Bhagyalakshmi S, Lavanya K. Formulation development and evaluation of glyburide beads for controlled release, Der Pharmacia Lettre, 2013; 5 (3):170-177.

4. Lohithasu D, Anil Kumar V, Ramana JV, Pratap A, Vamsi Krishna D, Shanmukh NA. Formulation development and evaluation of metoprolol succinate microbeads by ionotropic gelation method, Int J. Inv. Pharm.Sci., 2013; 1(3):221-230.

5. Lohithasu D, Ramana JV, Anil Kumar V, Pratap Anand N, Praveen G. Formulation and evaluation of metformin hydrochloride beads by using various polymers with sodium alginate, Der Pharmacia Lettre, 2013; 5 (4):56-61.

6. Harsha INS, Lohithasu D, ManoharBabu K, Madhu G, Lavanya K, Krishna Swaroop K. Formulation and characterization of piroxicam liquisolid technique for solubility enhancement. World J Pharma Pharm Sci, 2014; 3(3):1393-1404.

7. Lohithasu D, Ramana JV, Girish P, Harsha INS, Madhu G, Lavanya K, Swathi Sri D. A latest review on liquisolid technique as a novel approach, World J Pharm Res, 2014; 3(4): 479-493.

8. SantoshNaidu M, Radha GV, Girish P, Lohithasu D. Comparison studies on transdermal films of natural tamarind seed polysaccharide extract containing anti hypertension drug with PVA ,HPMC and guar gum, World J Pharm Res, 2014; 3(5): 753-763.

9. Lohithasu D, Midhun kumar D, Hemasundara Rao I. Design and evaluation of lafutidine floating tablets for controlled release by using semi-synthetic and natural polymer, J Drug Dis Therapeutics, 2014; 2 (23): 01-08

10. Chaithanya KM, Venkata Sirisha B, Lohithasu D ,Anu PJ, Janaki Devi S, Ramana Murthy K. Development and evaluation of poly ethylene oxide based chronotherapeutic drug delivery system of Olmesartan medoxomil, Indo American J Pharm Research, 2015; 5(4): 158-168.

11. Lohithasu D, Madhu Latha AVS, Midhun Kumar D, Girish P. Formulation and evaluation of Cordia dichotoma fruit mucilage as matrix forming agent for sustained release of propranolol hydrochloride. Int J Pharm, 2015; 5(2): 512-517.

12. Hema Naga Durga D, Lohithasu D, Ramana Murthy KV Development and stability studies of Diclofenac sodium controlled release dosage forms using various polymers. World J Pharma Pharm Sci, 2017; 6(11): 1160-1171.

13. Hema Naga Durga D, Lohithasu D, Ramana Murthy KV. Development and evaluation of Diclofenac sodium controlled release dosage forms using natural, hydrophilic and hydrophobic polymers and its comparative studies. Indian Journal of Pharmaceutical Education and Research, 2017; 51(1):116-127.

14. Hema Naga Durga D, Lohithasu D, Ramana Murthy KV. Isolation, Physico-Chemical Characterization and In-Vitro Drug Release Studies of Natural Polysaccharide of Araucaria heterophylla Gum. Indo American J Pharm Res, 2017; $7(6): 8153-72$.

15. Hema Naga Durga D, Lohithasu D, Ramana Murthy KV. Araucaria gum: novel natural polymer for controlled drug delivery. Development, in vitro and in vivo evaluation of Araucaria gum based matrix tablets for controlled release. Current Drug Delivery, 2017; 14(7): 955 - 967.

16. Sarada A, Lohithasu D, Soma Sundari M, Midhun Kumar D. Formulation Development, Characterization and In- vitro evaluation of floating matrix dosage form of Tramadol hydrochloride using various polymers. Asian J Pharm Clin Res, 2017; 10(2): 281-90.

17. Lohithasu D, Shabari Girinath K., Midhun Kumar D, Hema Naga Durga D. Applicability of natural polymers in transdermal patches: overview. World J Pharma Pharm Sci, 2016; 5(12): 513-27.

18. Hema Naga Durga D, Lohithasu D, Ramana Murthy KV. Isolation and Acute oral toxicity studies of Araucaria heterophylla novel natural polysaccharide gum in albino mice, World J Pharma Pharm Sci, 2016; 5(10): 702-11.

19. Lohithasu D, Ramana Murthy KV. Isolation and Evaluation of Binding property of Lannea coromandelica gum, Indian J Pharm Sci, 2016; 78(2):224-230.

20. Lohithasu D, Sarada A, Hema Naga Durga D, Rajya Lakshmi T. Assessment of film forming potential of Cordia dichotoma fruit mucilage (Boraginaceae): Alfuzosin hydrochloride as a drug of choices, J Applied Pharm Sci, 2016; 6 (05):036-043.

21. Sarada A, Lohithasu D, Chamundeswari V, Midhun Kumar D, Ramya S. Enhancement of dissolution rate of Ritonavir: a comparative study using various carriers and Techniques, Global J Pharm. 2015; 9(4):326-340.

22. Sarada A, Lohithasu D, Nikhil J, Janaki Devi S. Formulation and evaluation of gastro retentive matrix tablets of Atenolol using melt granulation technique, Int J Pharm science Res, 2016; $7(3): 1081-92$. 